\title{
Williamsia faeni sp. nov., an actinomycete isolated from a hay meadow
}

\author{
Amanda L. Jones, $†$ Gail D. Payneł and Michael Goodfellow \\ School of Biology, University of Newcastle, Newcastle upon Tyne NE1 7RU, UK
}

Correspondence

Amanda L. Jones

Amanda.L.Jones@northumbria. ac.uk
The taxonomic status of an actinomycete isolated from soil collected from a hay meadow was determined using a polyphasic approach. The strain, designated $\mathrm{N} 1350^{\top}$, had morphological and chemotaxonomic properties consistent with its classification in the genus Williamsia and formed a distinct phyletic line within the clade comprising the type strains of species of the genus Williamsia in the 16S rRNA gene tree. Strain $\mathrm{N}^{1350^{\top}}$ shared highest $16 \mathrm{~S}$ rRNA gene sequence similarities with Williamsia marianensis $\mathrm{MT}^{\top}$ (98.1\%) and Williamsia muralis MA140-96 ${ }^{\top}$ $(98.3 \%)$. However, strain $\mathrm{N} 1350^{\top}$ was readily distinguished from the type strains of Williamsia species using a combination of phenotypic properties. On the basis of these data, strain $\mathrm{N} 1350^{\top}$ is considered to represent a novel species of the genus Williamsia. The name proposed for this

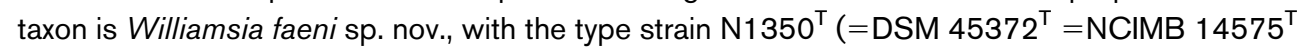
$=$ NRRL B-24794 ${ }^{\top}$.
The genus Williamsia (Kämpfer et al., 1999) has been classified in the family Nocardiaceae, together with the genera Gordonia, Millisia, Nocardia, Rhodococcus and Skermania (Zhi et al., 2009). At the time of writing, the genus encompasses five described species: Williamsia muralis (Kämpfer et al., 1999), the type species, isolated from indoor building material of a children's day centre in Finland, Williamsia deligens (Yassin \& Hupfer, 2006) from human blood, Williamsia marianensis (Pathom-Aree et al., 2006) from sediment taken from the Mariana Trench in the Pacific Ocean, Williamsia maris (Stach et al., 2004) from sediment collected from the Sea of Japan and Williamsia serinedens (Yassin et al., 2007) from an oil-contaminated soil. The type strains of these species form a clade within the evolutionary radiation occupied by the suborder Corynebacterineae (Stackebrandt et al., 1997; Zhi et al., 2009). The genus Williamsia can also be distinguished from the other mycolic acid-containing genera using a combination of chemotaxonomic and morphological properties (Soddell et al., 2006; Adachi et al., 2007). Similarly, species of the genus Williamsia can be distinguished from each other by using a range of phenotypic properties (Yassin et al., 2007). The aim of the present study was to determine the taxonomic position of an actinomycete, strain $\mathrm{N} 1350^{\mathrm{T}}$, that had been recovered from a hay meadow soil and provisionally assigned to the genus Williamsia.

tPresent address: School of Applied Sciences, Ellison Building, Northumbria University, Newcastle upon Tyne NE1 8ST, UK.

łPresent address: Agencourt Bioscience, 500 Cummings Center, Beverly, MA 01915, USA.

The GenBank/EMBL/DDBJ accession number for the 16S rRNA gene sequence of strain $\mathrm{N} 1350^{\top}$ is DQ157929.
Strain $\mathrm{N} 1350^{\mathrm{T}}$ was isolated from a soil suspension inoculum on Gauze's medium 2 supplemented with ( $\mu \mathrm{g}$ $\mathrm{ml}^{-1}$ ) cycloheximide (50), nalidixic acid (10), novobiocin (10) and nystatin (50) after incubation at $30{ }^{\circ} \mathrm{C}$ for 21 days (Tan et al., 2006). The soil sample had been collected from underneath the surface of Palace Leas meadow hay plot 6 (Atalan et al., 2000) at Cockle Park Experimental Farm, Northumberland, UK (national grid reference NZ 200913). Strain $\mathrm{N}_{1350^{\mathrm{T}}}$ was maintained on glucose-yeast extract agar (GYEA; Gordon \& Mihm, 1962) at room temperature and as glycerol suspensions $(20 \%, \mathrm{v} / \mathrm{v})$ at $-20{ }^{\circ} \mathrm{C}$. Biomass for the chemotaxonomic and 16S rRNA gene sequence analyses was grown in shake flasks of GYE broth for 5 days at $28{ }^{\circ} \mathrm{C}$, checked for purity and harvested by centrifugation. Cells for the chemosystematic studies were washed twice in distilled water and freeze-dried; cells for the $16 \mathrm{~S}$ rRNA study were washed in $\mathrm{NaCl} /$ EDTA buffer $(0.1 \mathrm{M}$ $\mathrm{NaCl}, 0.1 \mathrm{M}$ EDTA, pH 8.0) and stored at $-20{ }^{\circ} \mathrm{C}$ until required.

The phylogenetic position of strain $\mathrm{N} 1350^{\mathrm{T}}$ was determined in a $16 \mathrm{~S}$ rRNA gene sequence analysis. Isolation of chromosomal DNA, PCR amplification and direct sequencing of the purified products were carried out as described by Kim et al. (1998) The almost-complete 16S rRNA gene sequence (1441 nt) was aligned manually with corresponding sequences of representatives of genera classified in the suborder Corynebacterineae retrieved from the DDBJ/ EMBL/GenBank databases using the pairwise alignment option and 16S rRNA secondary structural information held in the PHYDIT program (available at http://plaza.snu.ac.kr/ $\sim$ jchun/phydit/). Phylogenetic trees were inferred using the least-squares (Fitch \& Margoliash, 1967), neighbour-joining (Saitou \& Nei, 1987), maximum-parsimony (Kluge \& Farris, 
1969) and maximum-likelihood (Felsenstein, 1981) treemaking algorithms from the PHYLIP suite of programs (Felsenstein, 1993) and evolution distance matrices were prepared according to Jukes \& Cantor (1969). The resulting unrooted tree topologies were evaluated in a bootstrap analysis (Felsenstein, 1985) based on 1000 resamplings of the neighbour-joining dataset using the CONSENSE and SEQBOOT options from the PHYLIP package.

The 16S rRNA gene phylogenetic tree is shown in Fig. 1. Strain $\mathrm{N} 1350^{\mathrm{T}}$ fell within the $16 \mathrm{~S}$ rRNA gene clade for the genus Williamsia. This association was supported by all of the tree-making algorithms and by a $100 \%$ bootstrap value in the neighbour-joining analysis. Strain $\mathrm{N}_{1350^{\mathrm{T}}}$ shared highest 16S rRNA gene sequence similarities with $W$. muralis MA140-96 ${ }^{\mathrm{T}}$ ( $98.3 \%$, corresponding to 24 nucleotide differences across 1416 locations) and $W$. marianensis $\mathrm{MT}^{\mathrm{T}}$ (98.1\%). DNA-DNA hybridization studies were not performed between these strains as $W$. marianensis $\mathrm{MT}^{\mathrm{T}}$ and W. muralis MA140-96 ${ }^{\mathrm{T}}$, which formed a subclade with strain $\mathrm{N} 1350^{\mathrm{T}}$, share a higher $16 \mathrm{~S}$ rRNA sequence similarity $(99.5 \%)$ with each other but a DNA-DNA relatedness value of only $11 \%$ (Pathom-Aree et al., 2006), which is well below the $70 \%$ cut-off point recommended for the delineation of bacterial species (Wayne et al., 1987).

Strain $\mathrm{N} 1350^{\mathrm{T}}$ was examined for key chemotaxonomic markers that are characteristic for the genus Williamsia. Standard procedures were used to determine the diagnostic isomers of diaminopimelic acid (Staneck \& Roberts, 1974), fatty acids (Sutcliffe, 2000), isoprenoid quinones (Collins, 1994), muramic acid type (Uchida et al., 1999), mycolic acids (Minnikin et al., 1975), polar lipids (Minnikin et al., 1984) and whole-organism sugars (Hasegawa et al., 1983).
Strain $\mathrm{N} 1350^{\mathrm{T}}$ contained meso-diaminopimelic acid, arabinose and galactose in whole-organism hydrolysates (wall chemotype IV sensu Lechevalier \& Lechevalier, 1970), Nglycolyl muramic acid and dihydrogenated menaquinones with nine isoprene units as the sole isoprenologue. The fatty acid profile included major proportions of straightchain saturated, unsaturated and tuberculostearic acids [fatty acid type 1b sensu Kroppenstedt, 1985; hexadecanoic $\left(\mathrm{C}_{16: 0}, 21 \%\right.$ of total $)$, monosaturated octadecanoic $\left(\mathrm{C}_{18: 1}\right.$, $15 \%)$, tridecanoic $\left(\mathrm{C}_{13: 0}, 11 \%\right)$, tuberculostearic (10-methyl $\left.\mathrm{C}_{18: 0}, 8 \%\right)$ and octadecanoic $\left(\mathrm{C}_{18: 0}, 7 \%\right)$ acids] and minor proportions of tetradecanoic $\left(\mathrm{C}_{14: 0}\right)$, pentadecanoic $\left(\mathrm{C}_{15: 0}\right)$, iso-hexadecanoic (iso- $\left.\mathrm{C}_{16: 0}\right)$ and eicosanoic $\left(\mathrm{C}_{20: 0}\right)$ acids. Phosphatidylethanolamine, phosphatidylglycerol, diphosphatidylglycerol and phosphatidylinositol were the major polar lipids. Strain $\mathrm{N} 1350^{\mathrm{T}}$ contained mycolic acids that comigrated with those from $W$. muralis DSM $44343^{\mathrm{T}}$. This chemotaxonomic profile is consistent with the classification of strain $\mathrm{N}_{1350^{\mathrm{T}}}$ in the genus Williamsia (Goodfellow \& Maldonado, 2006; Yassin \& Hupfer, 2006).

Strain $\mathrm{N} 1350^{\mathrm{T}}$ was examined for a range of phenotypic properties using a range of media and methods known to yield data of value for the classification and identification of mycolic-acid-containing actinomycetes (Jones et al., 2008). Strain $\mathrm{N} 1350^{\mathrm{T}}$ was aerobic, Gram-staining-positive, non-acid-alcohol-fast, asporogenous and catalase-positive and used a diverse range of compounds as sole carbon sources. These properties were in line with the classification of strain $\mathrm{N} 1350^{\mathrm{T}}$ in the genus Williamsia (Kämpfer et al., 1999; Yassin et al., 2007). Strain $\mathrm{N} 1350^{\mathrm{T}}$ could be readily distinguished from the type strains of Williamsia species using a combination of phenotypic properties (Table 1). Strain $\mathrm{N} 1350^{\mathrm{T}}$ could also be distinguished from $W$. deligens

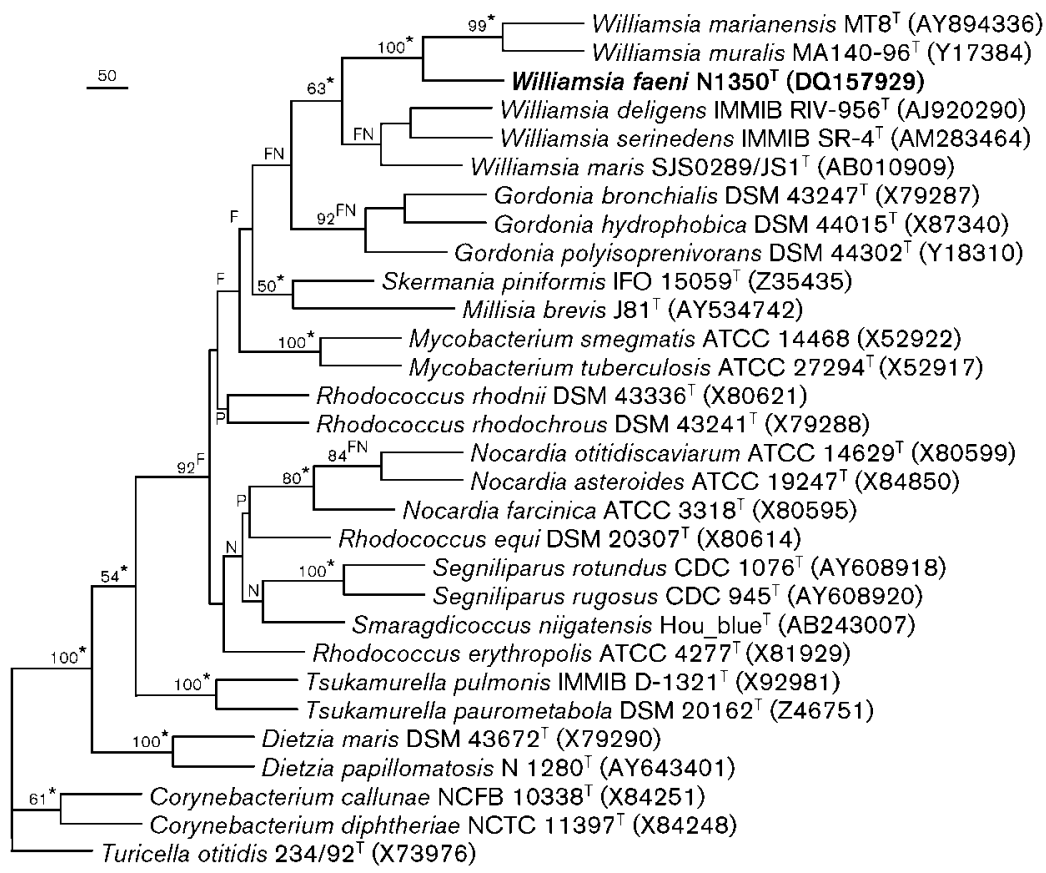

Fig. 1. Maximum-likelihood tree (Felsenstein, 1981) based on the nearly complete $16 \mathrm{~S}$ rRNA gene sequence of strain $\mathrm{N} 1350^{\top}$, showing the strain's relationships within the Williamsia clade. Asterisks indicate that the corresponding nodes were also recovered in trees generated with the least-squares (Fitch \& Margoliash, 1967), maximum-parsimony (Kluge \& Farris, 1969) and neighbour-joining (Saitou \& Nei, 1987) algorithms. $F, P$ and $N$ indicate that the corresponding nodes were also recovered in trees generated with the least-squares, maximum-parsimony or neighbour-joining algorithms, respectively. Bootstrap values ( $>50 \%$ ) based on a neighbour-joining analysis of 1000 resampled datasets are shown at branch nodes. Bar, 50 changes. 
Table 1. Phenotypic properties that distinguish strain $\mathrm{N} 1350^{\top}$ from the type strains of Williamsia species

Strains: 1, Williamsia faeni sp. nov. $\mathrm{N}_{1350^{\mathrm{T}}} ; 2$, W. marianensis DSM $44944^{\mathrm{T}}$ (data from Pathom-Aree et al., 2006); 3, W. muralis DSM $44343^{\mathrm{T}} ; 4, W$. deligens DSM $44902^{\mathrm{T}} ; 5, W$. maris DSM $44693^{\mathrm{T}} ; 6, W$. serinedens DSM $45037^{\mathrm{T}}$. Data were obtained in this study unless indicated. +, Positive; - , negative; ND, not determined.

\begin{tabular}{|c|c|c|c|c|c|c|}
\hline Characteristic & 1 & 2 & 3 & 4 & 5 & 6 \\
\hline \multicolumn{7}{|l|}{ Growth at $\left({ }^{\circ} \mathrm{C}\right)$ : } \\
\hline 4 & + & + & - & - & - & - \\
\hline 10 & + & + & + & - & + & + \\
\hline 37 & - & - & + & + & + & - \\
\hline 45 & - & - & + & - & - & - \\
\hline Aesculin hydrolysis & + & - & - & - & ND & - \\
\hline \multicolumn{7}{|l|}{ Growth with $(1 \%(\mathrm{w} / \mathrm{v})$ : } \\
\hline Adonitol & + & - & + & - & - & + \\
\hline$(-)$-L-Arabinose & + & + & - & - & - & + \\
\hline$(+)$-Cellobiose & + & - & - & - & - & - \\
\hline$(-)$-D-Galactose & + & - & - & - & - & + \\
\hline myo-Inositol & + & - & - & - & - & - \\
\hline$(+)$-Maltose & + & - & - & + & - & + \\
\hline (-)-D-Mannitol & + & + & + & + & - & + \\
\hline$(+)$-Melibiose & + & - & + & - & - & + \\
\hline$(+)$-D-Raffinose & + & - & - & - & - & - \\
\hline$\alpha$-L-Rhamnose & + & + & + & - & + & - \\
\hline (-)-D-Sorbitol & + & + & + & + & - & + \\
\hline$(+)$-Sucrose & + & + & + & + & - & + \\
\hline$(+)$-Trehalose & + & + & - & + & + & + \\
\hline$(+)$-D-Xylose & + & - & - & + & + & + \\
\hline \multicolumn{7}{|l|}{ Growth with $(0.1 \%, \mathrm{w} / \mathrm{v})$ : } \\
\hline$m$-Hydroxybenzoic acid & - & - & + & - & - & + \\
\hline p-Hydroxybenzoic acid & + & - & - & - & - & - \\
\hline \multicolumn{7}{|l|}{ Growth with $(1 \%, \mathrm{v} / \mathrm{v})$ : } \\
\hline 1,2-Propanediol & + & - & - & - & - & + \\
\hline
\end{tabular}

DSM $44902^{\mathrm{T}}$ and W. serinedens DSM $45037^{\mathrm{T}}$ by its ability to degrade L-tyrosine (Yassin \& Hupfer, 2006; Yassin et al., 2007) and from W. marianensis DSM $44944^{\mathrm{T}}$ by its ability to degrade tributyrin but not hypoxanthine (Pathom-Aree et al., 2006).

It can be concluded from the genotypic and phenotypic data that strain $\mathrm{N} 1350^{\mathrm{T}}$ can be readily distinguished from described Williamsia species and, hence, should be classified as a representative of a novel species in the genus Williamsia. The name proposed for this taxon is Williamsia faeni sp. nov.

\section{Description of Williamsia faeni sp. nov.}

Williamsia faeni (fae' ni. L. n. faenum hay; L. gen. n. faeni of hay, referring to the isolation of the type strain from a hay meadow).

Forms coccoid elements. Produces irregular, convex, matt yellow-pink-pigmented colonies on GYEA after incubation for 5 days at $28{ }^{\circ} \mathrm{C}$. Grows at $10-30{ }^{\circ} \mathrm{C}$, but not at $37{ }^{\circ} \mathrm{C}$. Exhibits chemotaxonomic markers characteristic of the genus Williamsia. Hydrolyses allantoin and urea, but not arbutin. Degrades DNA, RNA, starch and uric acid, but not adenine, chitin, elastin, xanthine or xylan. Uses (-)-Damygdalin, (-)-D-arabinose, (+)-D-arabitol, arbutin, $(-)$-D-fructose, $(-)$-D-fucose, $(-)$-D-glucose, inulin, $(+)$ lactose, (+)-D-mannose, (+)-melibiose, methyl $\alpha$-Dglucoside, $(-)$-D-ribose, $(+)$-turanose (all at $1 \%$, w/v), butan-1,3-diol, butan-1,4-diol, butan-1-ol, butan-2,3-diol, ethanol, propan-1-ol, propan-2-ol (all at 1\%, v/v), 3methyl-1-butanol (isoamyl alcohol), benzoic acid, fumaric acid, glycerol, glycogen, (+)-L-lactic acid, L-malic acid, oleic acid, propanoic acid, pyruvic acid, sodium acetate, sodium n-butyrate, $(+)$-L-tartaric acid, valeric acid and xylitol (all at $0.1 \%, \mathrm{w} / \mathrm{v}$ ) as sole carbon sources for energy and growth, but not dulcitol, salicin (all at $1 \%, w / v$ ), adipic acid, citric acid, glutaric acid, malonic acid, Dmandelic acid, oxalic acid, sebacic acid, suberic acid or succinic acid (all at $0.1 \%, \mathrm{w} / \mathrm{v}$ ). Uses acetamide, L-alanine, $\mathrm{L}-\alpha$-aminobutyric acid, L-arginine, L-gelatin, D-gluconic acid, L-glycine, histidine, L-leucine, DL-methionine, monoethanolamine, DL-norleucine, L-norvaline, DL-phenylalanine, L-proline, serine, uric acid, urea and L-valine as sole carbon and nitrogen sources, but not L-cysteine, L-glutamic acid, L-isoleucine or L-ornithine (all at $0.1 \%$, w/v). Additional phenotypic properties are indicated in the text and in Table 1. The fatty acid profile includes major amounts of hexadecanoic $\left(\mathrm{C}_{16: 0}\right)$, octadecenoic $\left(\mathrm{C}_{18: 1}\right)$, tridecanoic $\left(\mathrm{C}_{13: 0}\right)$, tuberculostearic (10-methyl $\left.\mathrm{C}_{18: 0}\right)$ and octadecanoic $\left(\mathrm{C}_{18: 0}\right)$ acids and minor amounts of tetradecanoic $\left(\mathrm{C}_{14: 0}\right)$, pentadecanoic $\left(\mathrm{C}_{15: 0}\right)$, iso-hexadecanoic (iso- $\left.\mathrm{C}_{16: 0}\right)$ and eicosanoic $\left(\mathrm{C}_{20: 0}\right)$ acids.

The type strain, $\mathrm{N} 1350^{\mathrm{T}}\left(=\mathrm{DSM} 45372^{\mathrm{T}}=\mathrm{NCIB} 14575^{\mathrm{T}}\right.$ $=$ NRRL B24794 $4^{\mathrm{T}}$ ), was isolated from a hay meadow plot at Cockle Park Experimental Farm, Northumberland, UK.

\section{Acknowledgements}

The authors are indebted to Dr Iain Sutcliffe (University of Northumbria) for help with the fatty acid analysis of strain $\mathrm{N} 1350^{\mathrm{T}}$.

\section{References}

Adachi, K., Katsuta, A., Matsuda, S., Peng, X., Misawa, N., Shizuri, Y., Kroppenstedt, R. M., Yokota, A. \& Kasai, H. (2007). Smaragdicoccus niigatensis gen. nov., sp. nov., a novel member of the suborder Corynebacterineae. Int J Syst Evol Microbiol 57, 297-301.

Atalan, E., Manfio, G. P., Ward, A. C., Kroppenstedt, R. M. \& Goodfellow, M. (2000). Biosystematic studies on novel streptomycetes from soil. Antonie van Leeuwenhoek 77, 337-353.

Collins, M. D. (1994). Isoprenoid quinones. In Chemical Methods in Prokaryotic Systematics, pp. 265-309. Edited by M. Goodfellow \& A. G. O'Donnell. Chichester: Wiley.

Felsenstein, J. (1981). Evolutionary trees from DNA sequences: a maximum likelihood approach. J Mol Evol 17, 368-376.

Felsenstein, J. (1985). Confidence limits on phylogenies: an approach using the bootstrap. Evolution 39, 783-791. 
Felsenstein, J. (1993). PHYLIP (phylogeny inference package), version 3.5c. Distributed by the author. Department of Genome Sciences, University of Washington, Seattle, USA.

Fitch, W. M. \& Margoliash, E. (1967). Construction of phylogenetic trees. Science 155, 279-284.

Goodfellow, M. \& Maldonado, L. A. (2006). The families Dietziaceae, Gordoniaceae, Nocardiaceae and Tsukamurellaceae. In The Prokaryotes: a Handbook on the Biology of Bacteria, 3rd edn, vol. 3, pp. 843-888. Edited by M. Dworkin, S. Falkow, E. Rosenberg, K. H. Schleifer \& E. Stackebrandt. New York: Springer.

Gordon, R. E. \& Mihm, J. M. (1962). Identification of Nocardia caviae (Erikson) nov. comb. Ann N Y Acad Sci 98, 628-636.

Hasegawa, T., Takizawa, M. \& Tanida, S. (1983). A rapid analysis for chemical grouping of aerobic actinomycetes. J Gen Appl Microbiol 29, 319-322.

Jones, A. L., Koerner, R. J., Natarajan, S., Perry, J. D. \& Goodfellow, M. (2008). Dietzia papillomatosis sp. nov., a novel actinomycete isolated from the skin of an immunocompetent patient with confluent and reticulated papillomatosis. Int J Syst Evol Microbiol 58, 68-72.

Jukes, T. H. \& Cantor, C. R. (1969). Evolution of protein molecules. In Mammalian Protein Metabolism, vol. 3, pp. 21-132. Edited by H. N. Munro. New York: Academic Press.

Kämpfer, P., Andersson, M. A., Rainey, F. A., Kroppenstedt, R. M. \& Salkinoja-Salonen, M. (1999). Williamsia muralis gen. nov., sp. nov., isolated from the indoor environment of a children's day care centre. Int J Syst Bacteriol 49, 681-687.

Kim, S. B., Falconer, C., Williams, E. \& Goodfellow, M. (1998). Streptomyces thermocarboxydovorans sp. nov. and Streptomyces thermocarboxydus sp. nov., two moderately thermophilic carboxydotrophic species from soil. Int J Syst Bacteriol 48, 59-68.

Kluge, A. G. \& Farris, J. S. (1969). Quantitative phyletics and the evolution of anurans. Syst Zool 18, 1-32.

Kroppenstedt, R. M. (1985). Fatty acid and menaquinone analysis of actinomycetes and related organisms. In Chemical Methods in Bacterial Systematics (Society for Applied Bacteriology Technical Series vol. 20), pp. 173-199. Edited by M. Goodfellow \& D. E. Minnikin. New York: Academic Press.

Lechevalier, M. P. \& Lechevalier, H. A. (1970). Chemical composition as a criterion in the classification of aerobic actinomycetes. Int J Syst Bacteriol 20, 435-443.

Minnikin, D. E., Alshamaony, L. \& Goodfellow, M. (1975). Differentiation of Mycobacterium, Nocardia, and related taxa by thin-layer chromatographic analysis of whole-organism methanolysates. J Gen Microbiol 88, 200-204.

Minnikin, D. E., O'Donnell, A. G., Goodfellow, M., Alderson, G., Athalye, M., Schaal, A. \& Parlett, J. H. (1984). An integrated procedure for the extraction of bacterial isoprenoid quinones and polar lipids. J Microbiol Methods 2, 233-241.
Pathom-Aree, W., Nogi, Y., Sutcliffe, I. C., Ward, A. C., Horikoshi, K., Bull, A. T. \& Goodfellow, M. (2006). Williamsia marianensis sp. nov., a novel actinomycete isolated from the Mariana Trench. Int J Syst Evol Microbiol 56, 1123-1126.

Saitou, N. \& Nei, M. (1987). The neighbor-joining method: a new method for reconstructing phylogenetic trees. Mol Biol Evol 4, 406425.

Soddell, J. A., Stainsby, F. M., Eales, K. L., Kroppenstedt, R. M., Seviour, R. J. \& Goodfellow, M. (2006). Millisia brevis gen. nov., sp. nov., an actinomycete isolated from activated sludge foam. Int J Syst Evol Microbiol 56, 739-744.

Stach, J. E., Maldonado, L. A., Ward, A. C., Bull, A. T. \& Goodfellow, M. (2004). Williamsia maris sp. nov., a novel actinomycete isolated from the Sea of Japan. Int J Syst Evol Microbiol 54, 191-194.

Stackebrandt, E., Rainey, F. A. \& Ward-Rainey, N. L. (1997). Proposal for a new hierarchic classification system, Actinobacteria classis nov. Int J Syst Bacteriol 47, 479-491.

Staneck, J. L. \& Roberts, G. D. (1974). Simplified approach to identification of aerobic actinomycetes by thin-layer chromatography. Appl Microbiol 28, 226-231.

Sutcliffe, I. C. (2000). Characterisation of a lipomannan lipoglycan from the mycolic acid containing actinomycete Dietzia maris. Antonie van Leeuwenhoek 78, 195-201.

Tan, G. Y., Ward, A. C. \& Goodfellow, M. (2006). Exploration of Amycolatopsis diversity in soil using genus-specific primers and novel selective media. Syst Appl Microbiol 29, 557-569.

Uchida, K., Kudo, T., Suzuki, K. \& Nakase, T. (1999). A new rapid method of glycolate test by diethyl ether extraction, which is applicable to a small amount of bacterial cells of less than one milligram. J Gen Appl Microbiol 45, 49-56.

Wayne, L. G., Brenner, D. J., Colwell, R. R., Grimont, P. A. D., Kandler, O., Krichevsky, M. I., Moore, L. H., Moore, W. E. C., Murray, R. G. E. \& other authors (1987). International Committee on Systematic Bacteriology. Report of the ad hoc committee on reconciliation of approaches to bacterial systematics. Int J Syst Bacteriol 37, 463464.

Yassin, A. F. \& Hupfer, H. (2006). Williamsia deligens sp. nov., isolated from human blood. Int J Syst Evol Microbiol 56, 193-197.

Yassin, A. F., Young, C. C., Lai, W. A., Hupfer, H., Arun, A. B., Shen, F. T., Rekha, P. D. \& Ho, M. J. (2007). Williamsia serinedens sp. nov., isolated from an oil-contaminated soil. Int J Syst Evol Microbiol 57, $558-561$.

Zhi, X. Y., Li, W. J. \& Stackebrandt, E. (2009). An update of the structure and 16S rRNA gene sequence-based definition of higher ranks of the class Actinobacteria, with the proposal of two new suborders and four new families and emended descriptions of the existing higher taxa. Int J Syst Evol Microbiol 59, 589-608. 